\title{
Alona kaingang (Crustacea, Cladocera, Aloninae): a new species of the pulchella- group, with identification key to Neotropical species
}

\author{
Francisco Diogo Rocha Sousa ${ }^{1,2^{*}}$, Lourdes Maria Abdu Elmoor-Loureiro ${ }^{2}$ and Sandro Santos ${ }^{1}$
}

\begin{abstract}
Background: The subfamily Aloninae has been the focus of extensive studies on the Chydoridae because it has a higher diversity of species and due to the necessity of a detailed redescription of many taxa, especially using characters related to thoracic appendages. The polyphyletic genus Alona was redefined recently, and many species complexes were translocated to natural groups. The pulchella-group is a candidate for removal from Alona because it forms a well-defined complex of species, besides possessing higher species diversity. At present, $50 \%$ of the known species occur in the Neotropics.
\end{abstract}

Results: In this study, we described Alona kaingang, a new species of pulchella-group distributed in southern South America. The new species shares with other species similarities in general features of limbs but, for instance, differs from South American Alona glabra because it has a short postabdomen. Alona kaingang sp. nov. differs from Andean Alona altiplana because it has thick denticles on the postabdomen and longitudinal lines on the carapace are absent. Differences in the limbs were also observed.

Conclusions: Alona kaingang sp. nov. is part of the group that contains species with complete connection between the main head pores. Like other species of the pulchella-group, A. kaingang sp. nov. also has similarities with the genus Ovalona. The relationship between these two species groups still needs to be tested.

Keywords: Chydoridae; Alona anamariae; Ovalona; Head pores; Limb; Postabdomen

\section{Background}

Chydoridae Dybowski \& Grochowski, 1894 emend. Frey, 1967 is the most speciose family of the superorder Cladocera (Crustacea: Branchiopoda). The majority of its species inhabit the littoral zones of inland waters, usually associated with aquatic vegetation or fine sediments (Smirnov 1971; Kotov 2006). The subfamily Aloninae Dybowski \& Grochowski, 1894 emend. Frey, 1967 has been extensively studied for two main reasons: (1) the high diversity of species and (2) the need for detailed redescriptions of taxa, especially using characters related

\footnotetext{
*Correspondence: sousa_bio@yahoo.com.br

1 Núcleo de Estudos em Biodiversidade Aquática, Programa de Pós-graduação em Biodiversidade Animal, Universidade Federal de Santa Maria—UFSM, Av. Roraima 1000, Camobi, Santa Maria CEP 97105-900, RS, Brazil

${ }^{2}$ Laboratório de Biodiversidade Aquática, Universidade Católica de Braślia-UCB, QS7 lote 1, Bloco M, sala 204, Taguatinga CEP 71966-700, DF, Brazil
}

to thoracic appendages (Smirnov 1998; Kotov 2000a, b; Sinev and Kotov 2000; Sinev 2001a; Sinev and Kotov 2001; Kotov and Elías-Gutiérrez 2002; Kotov 2003; Van Damme et al. 2003; Kotov and Sanoamuang 2004; Sinev and Elmoor-Loureiro 2010; Van Damme et al. 2010; Sinev and Atroschenko 2011).

Many of the recent morphological investigations and redescriptions of species within this subfamily were related to the genus Alona Baird, 1843 and resulted in the description of new genera or species translocations to correlated groups, such as Karualona Dumont \& SilvaBriano, 2000 (Dumont and Silva-Briano 2000; Sinev and Hollwedel 2005), Nicsmirnovius Chiambeng \& Dumont, 1999 (Kotov 2003; Van Damme et al. 2003), Parvalona Van Damme, Kotov \& Dumont, 2005 (Van Damme et al. 2005), Armatalona Sinev, 2004 (Sinev 2004a), Matralona 
Van Damme \& Dumont, 2009 (Van Damme and Dumont 2009), Maraura Sinev \& Shiel, 2008 (Sinev and Shiel 2008), Miralona Sinev, 2004 (Sinev 2004b), and Leberis Smirnov, 1989 (Sinev et al. 2005). Together, these studies highlighted the polyphyletic nature of Alona, which has been supported by phylogenetic analysis (e.g., ElmoorLoureiro 2004; Sacherová and Hebert 2003).

Recently, Van Damme and Dumont (2008a) redescribed Alona quadrangularis (O.F. Müller 1776) using specimens from the Palearctic region, where it was originally described. Based on the morphology of the postabdomen, terminal claws, and limb setae, these authors defined consistent diagnostic characters for the genus Alona. Subsequently, some species complexes that had previously been attributed to Alona sensu lato were studied and allocated to new genera, such as Phreatalona, which corresponds to the protzi-complex (Van Damme et al. 2009); Coronatella, which corresponds to the rectangula-complex (Van Damme and Dumont 2008b); Brancelia (Van Damme and Sinev, 2011) which corresponds to the hercegovinae-complex; and Anthalona Van Damme, Sinev \& Dumont, 2011, which includes species of the verrucosa-complex (Van Damme et al. 2011). However, several groups still require removal from Alona sensu lato, such as the pulchella-group (Van Damme et al. 2010).

The pulchella-group is a well-defined complex of species of Alona sensu lato characterized by postabdomen with marginal denticles merged and moderately developed and inner distal lobe (IDL) with three setae, seven setae on the exopodite of the third limb, reduced filter comb on the fifth limb, and two lateral aesthetascs on male antennules (for more details, see Sinev et al. 2012). The pulchella-group has at least 16 valid species and six species waiting for revision, which have been reported for all continents, except Antarctica (Sinev 2001b, c; Sinev 2002a; Sinev 2009; Kotov et al. 2010; Van Damme et al. 2010; Sinev et al. 2012; Sinev and Silva-Briano 2012).

In the Neotropics, the pulchella-group is highly diverse presenting species with the entire morphological range known for the group, including the specialized species Alona bromelicola Smirnov, 1988 (Sinev 2002a). Specifically for South America, there are reports of three species (Sinev 2001b; Kotov et al. 2010); however, the knowledge of the pulchella-group remains incipient. This manuscript is part of an extensive review concerning populations of Alona sensu lato in Brazil, aims to evaluate the morphology, and describes a new species of the pulchella-group.

\section{Methods}

Selected specimens were transferred to slides containing glycerin and dissected under a stereomicroscope. The morphology of appendages and other structures was studied using a phase-contrast microscope. Some animals were dehydrated in an acetone series (50, 70, 90 and $100 \%$ ) and critical pointdried or air-dried, mounted on aluminum stubs, coated with gold, and examined under a JEOL-JSM 7001F scanning electron microscope. Enumeration of limb setae and other structures proceeded from the epipodite to the gnathobase, without relation to homology, according to the recent literature (Van Damme and Dumont 2007; Sinev and Kobayashi 2012). Drawings were prepared using a camera lucida.

\section{Results}

\section{Systematics}

Class Branchiopoda Latreille, 1817

Order Anomopoda Sars, 1865

Family Chydoridae Dybowski \& Grochowski, 1894 emend. Frey, 1967

Subfamily Aloninae Dybowski \& Grochowski, 1894 emend. Frey, 1967

Genus Alona Baird, 1843

Alona kaingang Sousa, Elmoor-Loureiro \& Santos

(Figs. 1, 2, 3, and 4)

\section{Type material}

Holotype. Undissected, adult parthenogenetic female in a tube with $90 \%$ ethanol deposited at the Museum of Zoology of the University of São Paulo under access number MZUSP 29593. The label of the holotype is "Alona kaingang n. sp., 1 parth. + from Mostardas-Lagoa de São Simão, RS, Brazil, Holotype."

Paratypes. Two undissected adult parthenogenetic females in tubes with $90 \%$ ethanol, deposited at the Museum of Zoology of the University of São Paulo under access number MZUSP 29594. One adult parthenogenetic female and one adult male, undissected in tubes with $90 \%$ ethanol, deposited at the National Museum of Rio de Janeiro under access numbers MNRJ 23739 and MNRJ 23740. Eight specimens selected as paratypes (access number EL02477), and several unstudied individuals (access numbers EL02165 and EL02166) are deposited at the Laboratório de Biodiversidade Aquática, Universidade Católica de Brasília.

\section{Type locality}

Pond in São Simão, Mostardas, Rio Grande do Sul state, Brazil (30॰57'06" S, 5042' 29' W).

\section{Etymology}

The name kaingang refers to indigenous people who inhabited the southern portion of South America before the European colonization. The kaingang people were distributed in Southeastern and Southern Brazil, where the new species occurs.

\section{Material examined}

Twenty-three adult parthenogenetic females and five males from the pond in São Simão, Mostardas, Rio Grande do Sul state, Brazil (30 57' 06" S, 50 42' 29" W). Material collected by Lourdes M. A. Elmoor-Loureiro on 01.i.2002. Four adult parthenogenetic females from the Limnology 


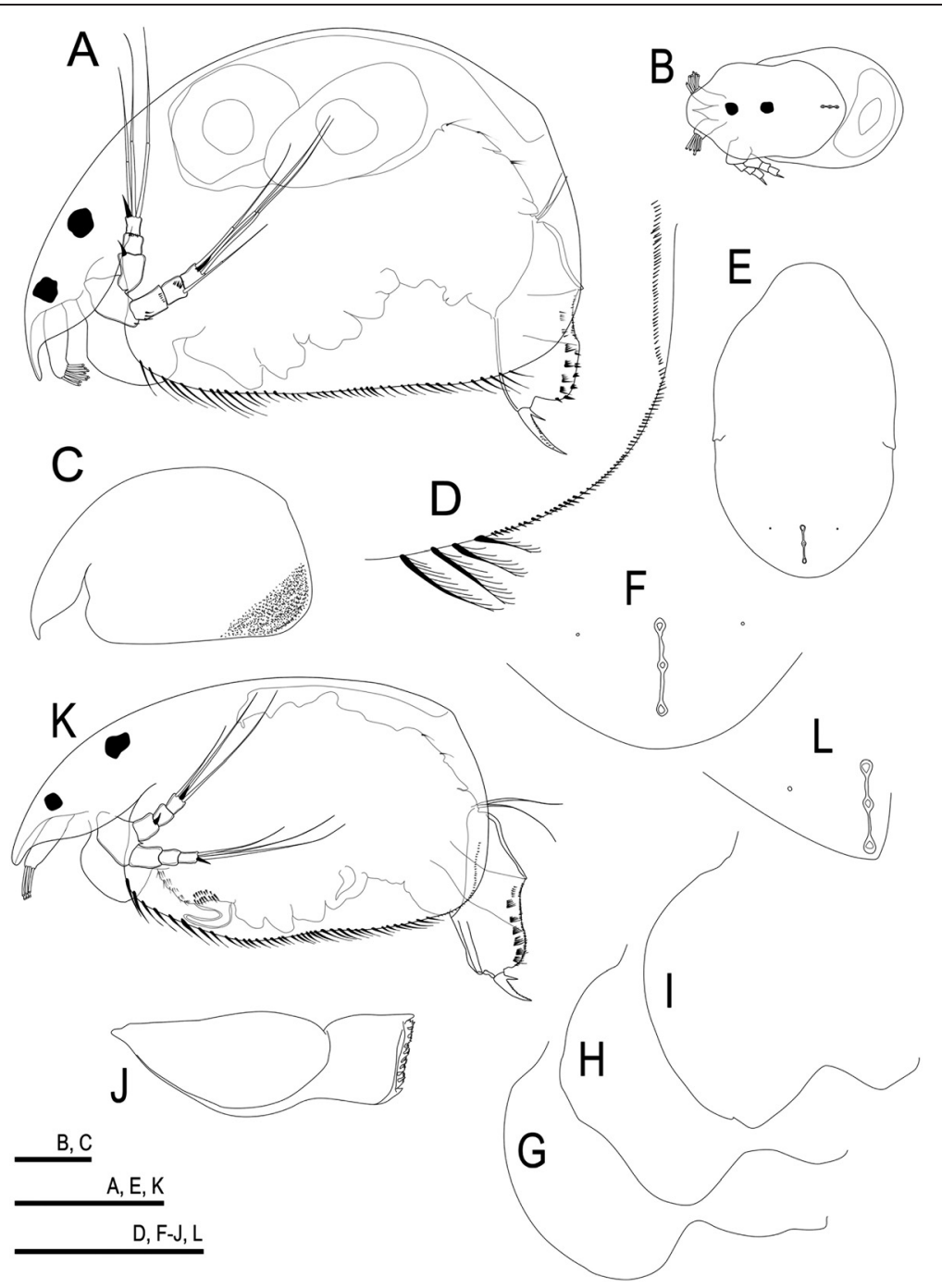

Fig. 1 Alona kaingang sp. nov., (a-j) adult parthenogenetic females from São Simão pond, Mostardas, Rio Grande do Sul, Brazil. (a) Habitus, lateral view; (b) dorsal view; (c) ornamentation on the carapace; $(\boldsymbol{d})$ posteroventral valve corner; $(\boldsymbol{e})$ head shield; $(\boldsymbol{f})$ head pores; $(\boldsymbol{g}-\boldsymbol{i})$ labral keel; $(\boldsymbol{j})$ mandible; $(\boldsymbol{k}-\boldsymbol{I})$ adult male from São Simão pond, Mostardas, Rio Grande do Sul, Brazil; ( $\boldsymbol{k})$ habitus, lateral view; $(\boldsymbol{l})$ head pores. Scale bar $=50 \mu \mathrm{m}$

Laboratory cultivation facility, Instituto de Ciências da Natureza, Universidade Federal de Alfenas; specimens collected at Furnas Reservoir, Minas Gerais state, Brazil $\left(21^{\circ} 03^{\prime} 24^{\prime \prime} \mathrm{S}, 46^{\circ} 00^{\prime} 18^{\prime \prime} \mathrm{W}\right)$, leg. M. J. SantosWisniewski (EL02167). Four adult parthenogenetic females from a marginal pond in São Simão Reservoir, Minas Gerais state, Brazil (18 $48^{\prime} 50^{\prime \prime} \mathrm{S}, 50^{\circ} 22^{\prime} 58^{\prime \prime}$ W); material collected by José Roberto DebastianiJúnior (EL02173).

\section{Diagnosis}

Female. Of small size, length $0.33-0.40 \mathrm{~mm}$. Body ovoid with dorsal margin strongly arched. In dorsal view, it shows weak lateral compression, dorsal keel absent. Head. Head shield with posterior margin rounded, rostrum short, three main head pores subequal in size, narrowly connected, postpore distance (PP) less than 0.2 interpore distance (IP). Lateral pores tiny, inserted midway between the main pores and the head shield margin. Labral keel wide, apex obtuse, without setae or denticles. Carapace. No striations or longitudinal lines. Ventral margin with 40-50 setae arranged in three groups. Posteroventral corner without denticles, with numerous spinules. Antennules. About 2-2.5 times as long as wide, four rows of setules on antennular body, distalmost row shorter than the others. Antennular sensory seta slender and long, about 1.5 times smaller than antennular body. Nine terminal aesthetascs of different sizes. Antenna. Antennal formula: spines 001/101, setae 113/003. Spine on first endopodite segment not exceeding the length of the second segment. Apical setae of endopodite and exopodite with lateral spinules. Postabdomen. Of moderate 


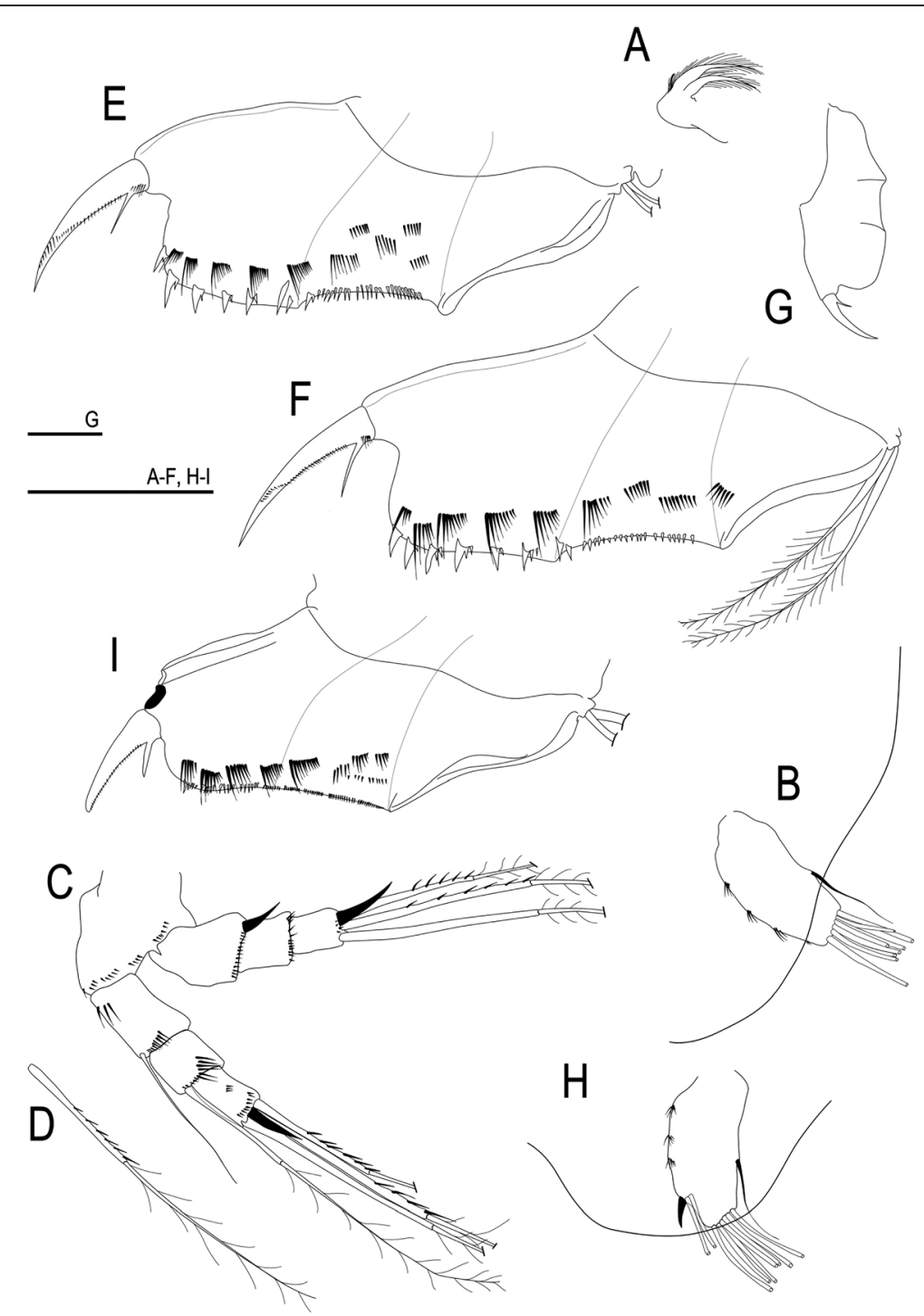

Fig. 2 Alona kaingang sp. nov., $(\boldsymbol{a}-\boldsymbol{g})$ adult parthenogenetic female. (a) first maxilla; (b) antennule; (c) antenna; (d) antenna terminal setae; (e) postabdomen (Lagoa de São Simão, Mostardas, Rio Grande do Sul); ( $\boldsymbol{f})$ postabdomen (São Simão Reservoir, Minas Gerais, Brazil); ( $(\boldsymbol{g})$ idem; $(\boldsymbol{h}-\boldsymbol{i})$ adult male from São Simão pond, Mostardas, Rio Grande do Sul, Brazil; (h) antennule; (i) postabdomen. Scale bar = $50 \mu \mathrm{m}$

size (about 2-2.4 times as long as wide). Pre-anal margin longer than anal margin and shorter than postanal margin. Anal margin inserted in a depression, with distinct angles. Lateral fascicles arranged in five to seven groups, first spines of each group thick and exceeding margin of postabdomen. Six to seven clusters of marginal denticles. Postabdominal setae with proximal portion naked, distal portion with short setules armed bilaterally. Terminal claw. Longer than anal margin, with one row of spinules on its base. Basal spine. Long, without spinules or setules. Limb I. First endite with two marginal setae, IDL with three setae; setae 2-3 bisegmented, long and with strong proximal spines. Limb II. Exopodite elongated, with setae present; scrapers $3,5,6,7$, and 8 with robust denticulation. Limb III. Exopodite with seven marginal setae; first seta longer than the second, fifth, and seventh setae less than half length of sixth seta, fourth setae geniculated. Limb IV. Exopodite with six marginal plumose setae; fourth seta thick and more than half length of fifth seta; sixth seta half as long as fifth seta. Limb $V$. Exopodite with slight depression in middle portion, with four plumose setae; seta 3 smaller than setae 1 and 2; Gnathobase without elements or setae. Male. Body elongated, smaller than female (length $0.27-0.30 \mathrm{~mm}$ ). Ventral margin armed with 40 setae followed by fine spinules. Posteroventral corner without denticles. Head with short rostrum. Main pores nearly connected. Lateral pore inserted between distal and median pores. Antennules. With three rows of short setules on the antennular body. Nine (juvenile) to 11 (adult) aesthetascs present: seven to nine terminal and 


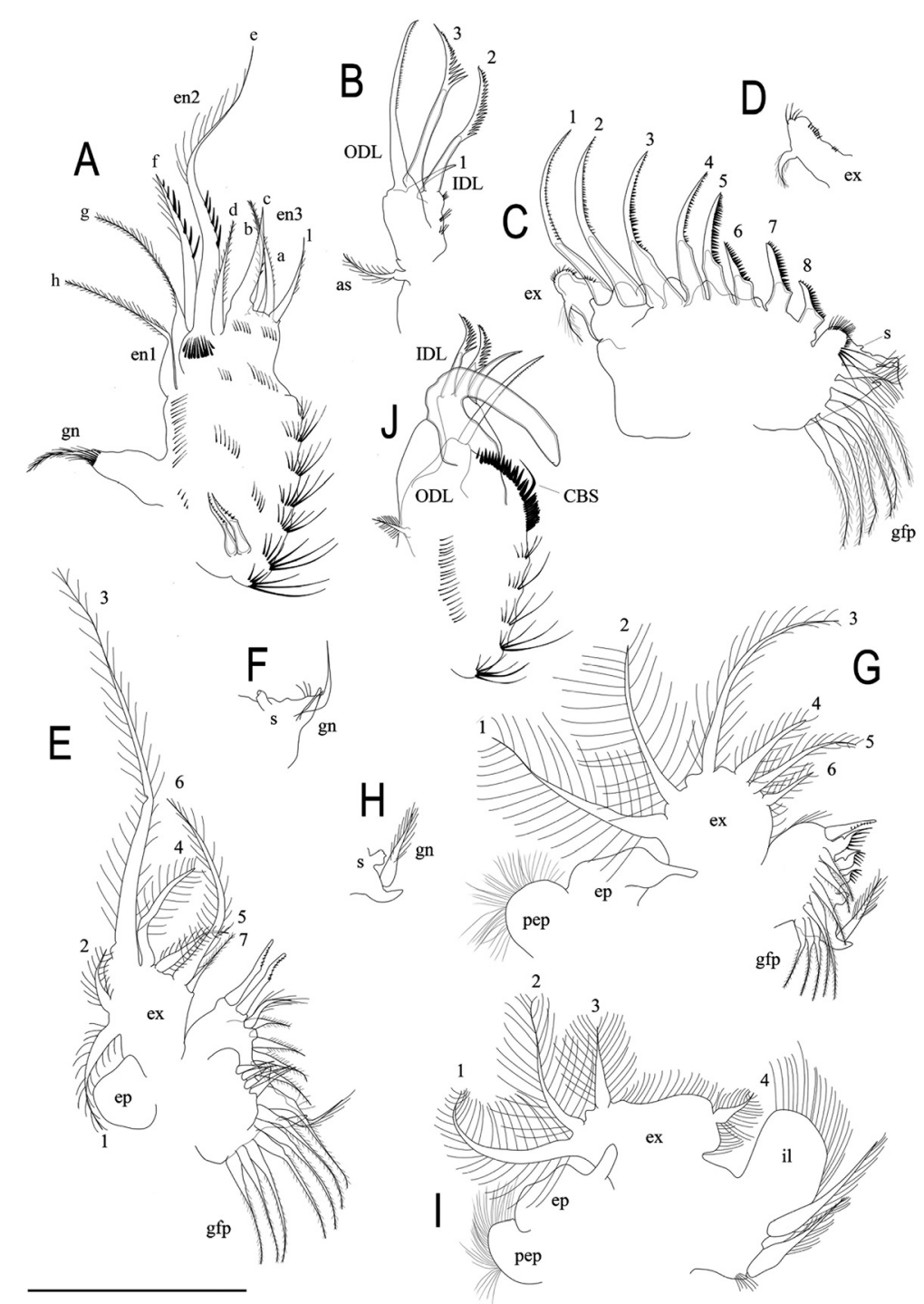

Fig. 3 Alona kaingang sp. nov., adult parthenogenetic females from São Simão pond, Mostardas, Rio Grande do Sul, Brazil. (a) limb l; (b) idem; (c)

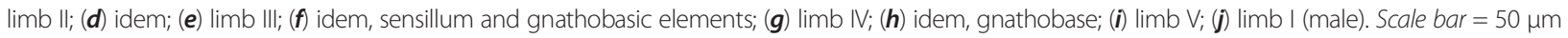

two lateral. Male seta short, thick, about 4.6 times shorter than length of antennular body. Postabdomen. Narrowing toward distal portion, anal angle not defined. Marginal clusters of spinules present, at least five postanal fascicles. Gonopores opening ventrally, subapically to terminal claw. Terminal claw. Smaller than that of female, tip blunt, with slender spinules implanted at base. Basal spine about onethird length of terminal claw. Limb I. With copulatory hook U-shaped; copulatory brush seta slender; IDL with three setae. Seta 1 long, thick, subequal in size to setae 2 and 3.

\section{Description of adult parthenogenetic female}

Habitus (Fig. 1(a-c)). Compared to other species of the genus, it is a small-sized animal $(0.33-0.40 \mathrm{~mm})$, colorless, and transparent. Carapace ovoid in lateral view, about 1.5 times as long as high, dorsal margin strongly arched. In dorsal view, it shows weak lateral compression. Dorsal keel absent.

Head (Fig. 1(a, e, f)). Ocellus as large as eye. Head shield about 1.7 times as long as wide, with posterior margin rounded. Rostrum short, blunt, projected toward ventral margin. Three main head pores of subequal size, narrowly connected (Fig. 4(a)), PP less than 0.2 IP. Lateral pores tiny, inserted midway between main pores and head shield margin. Labrum (Fig. 1(g-i)). Labral keel wide in lateral view, anterior margin slightly convex, apex obtuse, lateral projections not observed, without setae or denticles. In some specimens, the margin is subquadrangular (Fig. 1(h)) or with a small depression near 

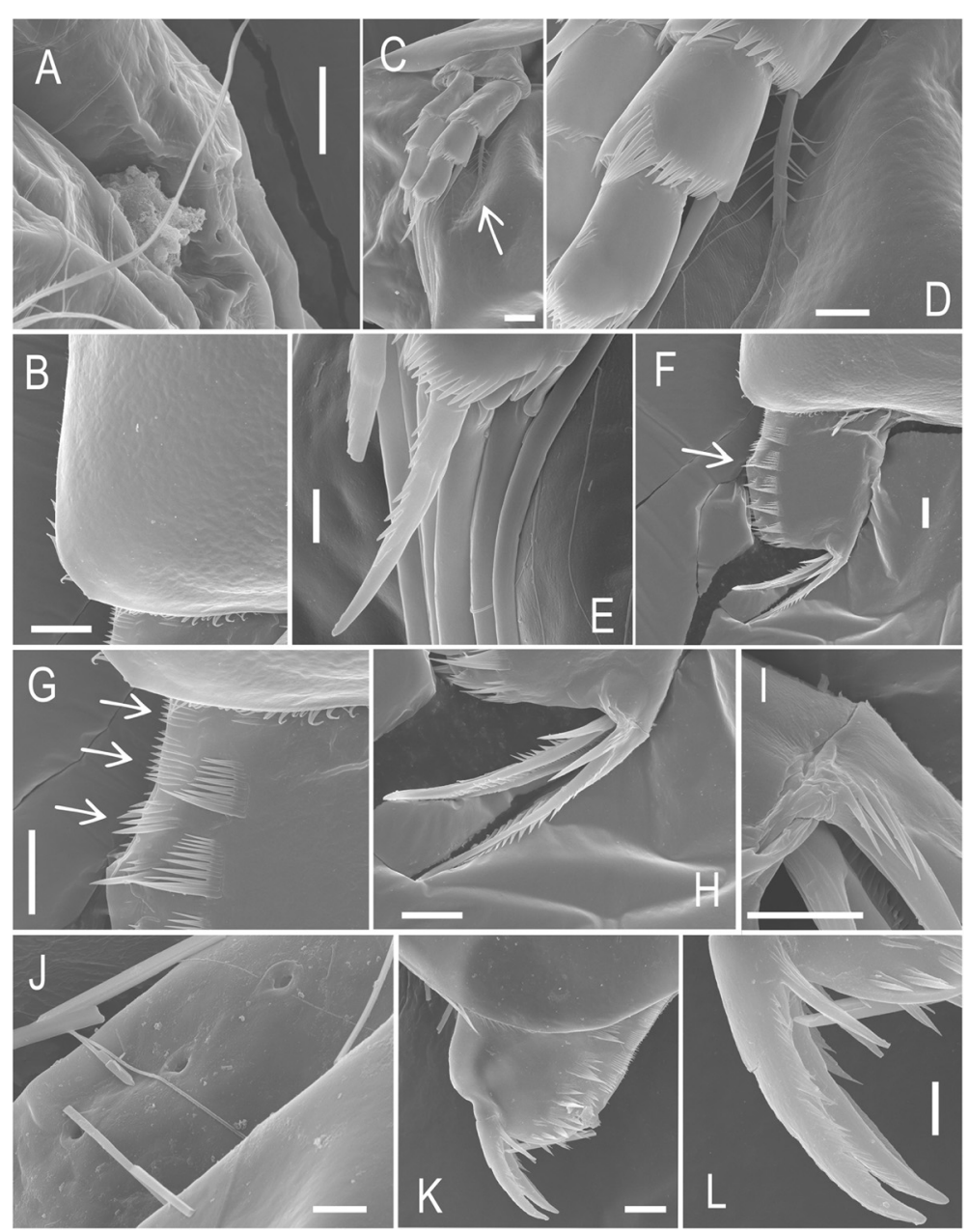

Fig. 4 Alona kaingang sp. nov., (a-i) adult parthenogenetic females from São Simão pond, Mostardas, Rio Grande do Sul, Brazil. (a) main head pores; (b) valves. (c) antenna - arrow showing seta on the first exopod segment; (d) idem. (e) antenna_apical spine on the first endopod segment; $(\boldsymbol{f})$ postabdomen — arrow showing spinules on the anal margin; $(\boldsymbol{h})$ terminal claw; $(\boldsymbol{i})$ idem—base with spinules; $(\boldsymbol{j}$ - $\boldsymbol{l})$ adult male from Lagoa de São Simão, Mostardas, Rio Grande do Sul, Brazil. (j) main head pores. (k) valves and postabdomen; (I) terminal claw. Scale bar indicates 5 $\mu \mathrm{m}$ to figures $(\boldsymbol{d}),(\boldsymbol{e}),(\boldsymbol{i}),(\boldsymbol{j}),(\boldsymbol{D}) ; 10 \mu \mathrm{m}$ to figures $(\boldsymbol{a}),(\boldsymbol{b}),(\boldsymbol{c}),(\boldsymbol{f}),(\boldsymbol{g}),(\boldsymbol{h}),(\boldsymbol{k})$

the apex (Fig. 1(i)). Mandible (Fig. 1(j)). Well developed in relation to body size (Fig. 1(a)). First maxilla (Fig. 2(a)). Relatively well developed, with two long setulose setae.

Carapace (Figs. 1(c, d) and 4(b)). No striations or longitudinal lines (Fig. 4(b)), punctuated ornamentation observed in optical microscopy. Ventral margin straight, with 40-50 setae arranged in three groups, proximal group long, middle group short, posterior group increasing in size toward posteroventral corner. These setae are followed by spinules not arranged in groups, proximalmost spinule projecting beyond margin.

Antennules (Fig. 2(b)). Reaching the tip of the rostrum, setae sometimes exceeding it, about 2-2.5 times longer than wide, four rows of setules on antennular body, distalmost row shorter than the others. Antennular sensory seta slender and long, about 1.5 times smaller than antennular body, inserted at two thirds of antennule length, counting from the base. Nine terminal aesthetascs of different sizes. None of these aesthetascs exceed the length of the antennules.

Antenna (Figs. 2(c, d) and 4(e)). Coxal setae not studied. Basipodite thick, with many spinules and one long spine. First exopodite segment with long thick spinules near the base (3-4) and terminal portion. Second exopodite segment with long thick spinules on the terminal portion. Endopodite segments with short spinules. Antennal formula: spines $001 / 101$, setae $113 / 003$. Seta on first exopodite segment thick and plumose (Fig. 4(c, d)), not reaching mid length of terminal setae. Seta on second exopodite bisegmented, long, with many setules. Spine on first endopodite segment without denticles, reaching but not exceeding distal end of second segment. Apical spines of endopodite and exopodite of different sizes, with denticles (Fig. 4(e)). Two apical setae 
of endopodite and exopodite with spinules, which are larger on the first segment.

Abdomen. About two times shorter than thorax. Two or three abdominal setae (Fig. 1(a)).

Postabdomen (Fig. 2(e-g)). Moderate size, relatively wide, about 2-2.4 times as long as wide, ventral margin slightly rounded, with at least three rows of spinules. Preanal margin longer than anal margin and shorter than postanal margin. Anal margin concave, clearly inserted in a depression and with two distinct angles (Fig. 4(f-g)), with many spinules forming groups (Fig. 4(g)). Postanal margin rounded, not projected. Lateral fascicles arranged in five to seven groups, first spines of each group thick and exceeding margin of postabdomen. Six to seven clusters of marginal denticles, distal ones with two to three marginal denticles (apparently fused when observed in optical microscopy but superimposed in layers when observed in SEM (Fig. 4(f)); proximal denticles may be separated; length of the marginal denticles on the postanal margin of the postabdomen about two times longer than the width of the base of the denticles. Postabdominal seta (Fig. 2(e)). Approximately half as long as postabdomen, proximal portion naked. Short setules armed bilaterally, inserted toward distal portion. Terminal claw (Fig. 2(eg)). Implanted at projected basis from the postabdomen, longer than anal margin, uniformly curved, with one row of spinules on the base (Fig. 4(i)); pecten armed with rows of internal and external spinules; inner row composed of robust spinules; outer row with spinules increasing in size toward distal region (Fig. 4(h)). Basal spine long, about two times as long as width of claw at its base, without spinules or setules.

\section{Five pairs of limbs}

Limb I (Fig. 3(a, b)). Epipodite not studied. Outer distal lobe (ODL) with thin seta, serrulate in distal part, about same size as the longest IDL seta. Accessory seta relatively small, setulated, and implanted near base of ODL. IDL with three groups of spinules on its face, three setae present; seta 3 smaller than the others, naked. Setae 2-3 bisegmented, long, and with strong proximal spines and narrow distal portion with short denticles. Third endite with four setae, one of them thinner than the others (1); inner seta densely setulated, longer than the other two ( $a, b)$. Second endite with one row of spinules; three setae of different sizes, seta 4 (e) about 2.7 times longer than seta 3 (f) and about 4.3 times longer than seta 5 (d); setae 3-4 (d-f) with thick spinules on the lateral face, seta 4 (e) with spinules not exceeding median portion; seta 5 (d) about half length of seta 3 (f). First endite with two marginal setae $(\mathrm{g}, \mathrm{h})$, bisegmented, similar in size and slightly setulated. No specialized elements on endites. Ejector hooks similar in size. Ventral face of limb with seven rows of setules organized in clusters, decreasing toward distal portion. Gnathobase thick, corresponding to a densely setulated seta.

Limb II (Fig. 3(c, d)). Exopodite elongated, with tiny proximal spinules, and distally setulated. Seta on exopodite present, setulated, about two to three times smaller than the exopodite itself. Endite armed with eight scrapers gradually decreasing in size toward the gnathobase, sixth and eighth scrapers smaller than seventh. Scrapers 1, 2, and 4 armed with fine denticulation, other scrapers with robust denticulation. Proximal portion of gnathobase wide, apex armed with fine spinules followed by long setules (in the populations from Minas Gerais state, these appear shorter, thinner, and more numerous), distal portion armed with sensillum and three elements, first element geniculated and setulated. Filter comb with seven setae, first seta short and densely setulated; other setae long, with setules and implanted from median portion.

Limb III (Fig. 3(e, f)). Epipodite round, without evident projections (in the populations from Minas Gerais state, long projections were observed). Exopodite subquadrangular, with seven marginal setae arranged in $2+5$. First seta longer than second; third seta about 1.8 times longer than sixth seta; fourth seta geniculated; fifth and seventh setae less than half length of sixth seta; all setae are plumose, except the seventh. Distal endite with three setae, two scraper-like of different sizes, third seta geniculated and armed with many setules implanted bilaterally; four plumose setae, increasing in size towards the gnathobase. Basal endite with four soft setae, increasing in size towards the base. Gnathobase armed with four elements, first a cylindrical sensillum, second a strong geniculated seta, setulated on the base, third and fourth elements with acute tip and without setules. Filter comb with seven long setae.

Limb IV (Fig. 3(g, h)). Pre-epipodite round, densely setulated, epipodite oval with short projections. Exopodite round with six marginal plumose setae; setae 1 and 2 subequal in size, third seta longer than all others, fourth seta thick exceeding the half length of fifth seta; sixth seta half as long as fifth seta. Distal endite with four setae, one scraper-like and three flaming-torch-like, decreasing in size toward the base. Basal endite with three soft setae, increasing in size toward the base. Gnathobase armed with one globular sensillum and a setulated seta implanted on robust base. Filter plate with five slender setae.

Limb $V$ (Fig. 3(i)). Pre-epipodite round and densely setulated, epipodite with short projections. Exopodite rectangular, not divided in lobes, about twice as long as wide, slight depression in the middle portion; four plumose setae, decreasing in size toward internal lobe; setae 1 and 2 subequal in size, seta 3 markedly smaller than setae 1 and 2; seta 4 about half length of seta 3 . Internal lobe wide, oval and with long setules; two setulated setae 
of similar size on the inner face of the lobe, no elements between these setae. Gnathobase reduced, without elements or setae.

Ephippial female: Unknown.

\section{Description of male}

Habitus (Fig. 1(k)). Smaller than female, length 0.27$0.30 \mathrm{~mm}$, about 1.6 times as long as high. Body elongated, weak lateral compression, body less arched than in female. Head with short rostrum, ocellus smaller than eye. Main pores close to each other, nearly connected, lateral pores tiny and arranged in different positions than in females (between distal and median pores; Fig. 1(1)). Carapace without punctuated ornamentations or longitudinal lines (Fig. 4(k)), ventral margin armed with 40 setae followed by fine spinules, the most proximal exceeding the line of posterior margin.

Antennules (Fig. 2(h)). Slightly exceeding the tip of the rostrum, about two times as long as wide, with three rows of short setules on antennular body; seven (juvenile) to nine (adult) aesthetascs of different sizes (none of these aesthetascs exceeds the length of antennules). Two lateral aesthetascs of different sizes, about half as long as antennular body; sensory seta long, about 1.4 times shorter than antennular body. Male seta short, thick, about 4.6 times shorter than length of antennular body, inserted at three thirds of antennular length, counting from base.

Antenna as described for females.

Postabdomen (Fig. 2(i)). Smaller than in female, narrowing distally; anal margin longer than postanal margin, angles not defined; marginal clusters of spinules present (Fig. 4(k)); at least five postanal fascicles, distalmost fascicle exceeding the margin line; anal margin with spinules differentiated in three groups; gonopores opening ventrally, subapically to terminal claw. Terminal claw smaller and thicker than in female, tip not acute (Fig. 4(1)). Slender spinules implanted at the base of terminal claw (as in the female). Basal spine about onethird length of terminal claw.

Limb I (Fig. 3(j)). Smaller than in female, copulatory hook U-shaped. Copulatory brush present, copulatory brush seta slender; IDL with three setae, smaller than corresponding setae of female, seta 1 long, thick, subequal in size to the other two setae, setae 2 and 3 bisegmented and with strong proximal spines (as in female).

\section{Differential diagnosis}

Alona kaingang sp. nov. is a member of the pulchellagroup because its posteroventral corner of the carapace is armed with many short and thin spinules not arranged in groups, three main head pores, marginal denticles of postabdomen merged and developed, lateral fascicles developed, IDL with three setae, seven setae on the exopodite of limb III, fourth setae of limb III well-developed, gnathobase of limb V reduced, and limb VI absent. Alona kaingang sp. nov. also has the fourth seta on the exopodite of limb III geniculated, like many species of the pulchella-group (except in Alona archeri). As an alternative to identification, the pulchella-group may be separated into two groups based on the morphology of the main head pores: one group contains species with interrupted connection (including those species with main head pore isolated) and the other contains species with complete connection. Thus, A. kaingang sp. nov., having a complete connection between the main head pores, could be differentiated from species belonging to do the first group: Alona capensis (Rüher, 1914), Alona setulosa (Megard, 1967), Alona cambouei (Guerne \& Richard, 1893), Alona aguascalientensis Sinev \& SilvaBriano, 2013, Alona nigra Smirnov, 1996, Alona setuloides Smirnov \& Timms, 1983, Alona azorica Frenzel \& Alonso 1989, Alona anastasia Sinev Alonso, Miracle \& Suhaquillo, 2012, and Alona nuragica Margaritora, 1971. Regarding species with complete connection between main head pores, A. kaingang sp. nov. is distinguished by the presence of spinules on apical setae of antenna and proximal spines on IDL setae. Besides, A. kaingang sp. nov. has single morphological traits such as the slight depression in the middle portion of the exopodite of the limb V.

\section{Ecology and distribution}

Alona kaingang sp. nov. has populations occurring in water bodies of the subtropical region of South America. Until now, A. kaingang sp. nov. has been found only in Minas Gerais state (São Simão and Furnas Reservoirs) and Rio Grande do Sul state (São Simão pond), Brazil. However, we expect that its geographical distribution is broader in the subtropical zone, because A. kaingang sp. nov. might be confused with Coronatella rectangula (Sars, 1861). This latter species likely does not occur in the Neotropics (Van Damme and Dumont 2008b), but there are many records in different Brazilian hydrographic regions (see Green 1972; Smirnov and Santos-Silva 1995; Eskinazi-Sant'Anna et al. 2005; Sterza and Fernandes 2006; Rocha et al. 2011), including the Furnas Reservoir (Santos et al. 1994; Viti et al. 2013). The review of Coronatella in Brazil confirmed that $C$. rectangula does not occur in Brazil, and probably not in the Neotropics (Sousa et al. 2015).

São Simão pond is located on the coastal plain of Rio Grande do Sul state and is part of the coastal wetland complex between the Atlantic Ocean and Patos Lagoon. São Simão pond does not connect with the ocean. The abiotic parameters of the pond water were as follows:

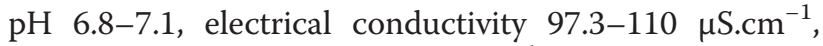
total phosphorus $0.104-0.139 \mathrm{mg} . \mathrm{L}^{-1}$, ammoniacal nitrogen 0.051-0.11 mg. $\mathrm{L}^{-1}$, dissolved oxygen 7.2-9.1 mg. $\mathrm{L}^{-1}$, 
and temperature $17-17.5{ }^{\circ} \mathrm{C}$ (data available from State Foundation of Environmental Protection Henrique Luiz Roessler-FEPAM, referring to the year when the type material was collected).

Furnas Reservoir, located in Minas Gerais state, is the largest reservoir in southeastern Brazil, with a total area of approximately $1440 \mathrm{~km}^{2}$. Recent data indicate that water temperature ranges between 24 and $28{ }^{\circ} \mathrm{C}, \mathrm{pH}$ is approximately 7 , electrical conductivity $19-22 \mu \mathrm{S} . \mathrm{cm}^{-1}$, total nitrogen $210-318 \mu \mathrm{g} . \mathrm{L}^{-1}$, total phosphorus $13-29$ $\mu \mathrm{g} . \mathrm{L}^{-1}$, and dissolved oxygen $8-9 \mathrm{mg} . \mathrm{L}^{-1}$ (Santos et al. 2010).

São Simão Reservoir is located on the boundary between Goiás and Minas Gerais states. Currently, it is being impacted by the uncontrolled increase in urban areas and farmland in its surroundings. This has led to eutrophication of the reservoir (Fonseca 2010).

The biology of $A$. kaingang sp. nov. is not well known. It inhabits the littoral zones of water bodies, probably among aquatic vegetation. Based on the present records, it should be found in different kinds of ecosystems: reservoirs, wetlands, and coastal lagoons. We believe that this species may occur in habitats with varying degrees of salinity. Alona kaingang sp. nov. is presumed to be an active scraper of substrates, based on the strong scrapers found in the limbs I and II (Fryer 1968; Van Damme et al. 2011).

\section{Identification key for species from the pulchella-group with occurrence in the Neotropics (adult parthenogenetic females)}

1. Basal spines very short, less 0.1 of the length claw, aesthetascs length about 2.6 times shorter than antennular body. A. bromelicola-Central America (Sinev 2002b)

- Basal spine longer than 0.1 of the length of the claw, aesthetascs length about 1.6-2 times shorter than antennular body.

2. Labral keel with two rows of short setules. .3

- Labral keel naked. 4

3. Postabdomen narrowing distally, basal segment of the apical setae of antenna without spines, one seta markedly longer than the others on the anterior group on the ventral margin of the carapace,.... ...Alona anamariae-Endemic from the Central Plateau of Mexico (Sinev and Silva-Briano 2012)

- Postabdomen wide and truncated, basal segment of the apical setae of antenna with spines, setae of the anterior group on the ventral margin of the carapace not differentiated in length A. setulosa-From North Canada to North Mexico (Sinev, 2009; Sinev and Silva-Briano 2012)

4. Abdomen armed with two to three rows of setules

- Abdomen armed with five to six rows of long setules.......... nigra-Bolivia and North Chile on the Andes (Kotov et al. 2010)

5. Main head pores connected 6

- Main head pores disconnected......................... A. aguascalientensis-Endemic of the Central Plateau of Mexico (Sinev and Silva-Briano 2012)

6. Antenna, spine on the first segment of the endopodite shorter than second segment..........................................

- Antenna, spine on the first segment of the endopodite of the same length of the second segment. A. kaingang sp. nov-Southern South America

7. Carapace ornamented with longitudinal lines, length of the postabdomen about 2.5 height, postanal margin armed with 5-6 denticles.........Alona altiplana-Endemic from Andes (Kotov et al. 2010)

- Carapace without longitudinal lines, length of the postabdomen about 2.8-3 height, postanal margin armed with seven to eight denticles. Alona glabra-Common in the Neotropics (Sinev 2001b; Sinev and Silva-Briano 2012)

\section{Discussion}

The presence of main head pores with complete connection may be taken as the main morphological trait uniting $A$. kaingang sp. nov. with valid species Alona pulchella (Herrick, 1884), A. archeri (Sars, 1888), A. altiplana Kotov, Sinev \& Berrios, 2010, A. glabra (Sars, 1901), A. bromelicola (Smirnov, 1988), A. karelica Stenroos, 1897 , and A. anamariae Sinev \& Silva-Briano, 2012. Among these species, the postabdomen of A. kaingang sp. nov. is quite similar to other species that present short postabdomen: the Chilean A. altiplana and the Mexican $A$. anamariae. All other species aforementioned have an elongated postabdomen (Sinev and Silva-Briano 2012).

Alona kaingang sp. nov. (length $0.33-0.40 \mathrm{~mm}$ ) is smaller than $A$. altiplana $(0.35-0.50 \mathrm{~mm})$. Besides, $A$. kaingang sp. nov. differs from $A$. altiplana because its carapace does not have longitudinal lines (Fig. 4(b)). In 
A. kaingang sp. nov., the length of the marginal denticles on the postanal margin of the postabdomen is about two times longer than the width of the base of the denticles (Fig. 2(e-f)) while in A. altiplana, this proportion is about 2.5-3 times longer (Kotov et al. 2010). The following morphological traits of the limbs are observed in $A$. kaingang sp. nov. but not in A. altiplana: (1) seta e on the endite 2 of the limb I about two times longer than seta $f$, (2) setae $2-3$ of the IDL markedly different in length, (3) setae 2-3 of the IDL armed with proximal spines, (4) scrapers 5-8 armed with strong denticles, (5) absence of specialized structure on the endite of the limb III, (6) seta 5 on the exopodite of the limb IV longer than setae 5-6, and (7) seta 3 on the exopodite of the limb V shorter than setae 1-2.

Regarding the size, A. kaingang sp. nov. (length 0.33$0.40 \mathrm{~mm})$ is longer than $A$. anamariae $(0.28-0.30 \mathrm{~mm})$ (Sinev and Silva-Briano 2012). In A. anamariae, the labral keel has two rows of setules, while in A. kaingang sp. nov., the labral keel is naked (Fig. 1(g-i)). In A. kaingang sp. nov., PP is less than 0.2 IP while in A. anamariae, PP is about 0.2-0.3 IP. Another important morphological trait observed in A. anamariae and that is absent in A. kaingang sp. nov. is the longest setae on the anterior group of margin of the carapace (Sinev and Silva-Briano 2012). The postabdomen of $A$. anamariae does not have postanal angle as evident as in A. kaingang sp. nov (Fig. 2(e-f)). On the limbs, $A$. kaingang sp. nov. differs from $A$. anamariae because it has (1) setae 2-3 of the IDL markedly of different length, (2) setae $2-3$ of the IDL armed with proximal spines, (3) scrapers 5-8 armed with strong denticles, (4) absence of a specialized structure on the endite of the limb III, (5) first flaming torch relatively robust, and (6) seta 5 on the exopodite of the limb III shorter than seta 7.

Recently, Sinev et al. (2012) described the Mediterranean A. anastasia, which has a distinct short postabdomen; however, this species may be easily separated from $A$. kaingang sp. nov. by the interrupted connection of the main head pores and absence of seta on the exopodite of the limb II. Alona setulosa is another species of the pulchella-group with a short postabdomen (Sinev 2009), and the shape of this structure is quite similar to that observed in A. kaingang sp. nov. Besides that, A. setulosa and A. kaingang sp. nov. share similar armature of the apical setae of the antenna and denticulation of scrapers 6-8. The armature of the apical setae of the antenna observed in A. setulosa and $A$. kaingang sp. nov. was also found in phylogenetically distant groups such as Armatalona (Sinev 2004a) and Acanthalona (Sinev and Kobayashi, 2012), which suggests that this morphological similarity may be the result of convergence. Alona setulosa differs from $A$. kaingang sp. nov. because it has a labral keel with two rows of setules and incomplete connection between main head pores. They differ also in fine features of the limbs (see Sinev 2009).

The differences between the other species that possess main head pores with complete connection and A. kaingang sp. nov. go beyond the shape of the postabdomen. The South American A. glabra has the third seta on the exopodite of the limb V longer than the second seta, and the first flaming torch on the limb IV is relatively thinner (Sinev 2001b). Besides that, the geographical distribution of $A$. glabra extends from Argentina to the extreme North of the Neotropics, while A. kaingang sp. nov. is restricted to the southern regions. Alona archeri has a PP less than 0.5 IP, well-developed distal denticles on the postabdomen transformed in setules toward the anal margin and seta 4 on exopodite of the limb III relatively straight and markedly long (Sinev 2002b). The paleotropical $A$. pulchella has thin setules on the scrapers of the limb II and relatively long second setae on the exopodite of the limb III (Sinev 2001c). The specialized $A$. bromelicola has a markedly short seta on the exopodite of the limb II, setae 6-4 on the exopodite of the limb IV of similar length, seta 3 is of similar length to setae 1-2 and seta 5 is markedly long, and the basal spine is very short (Sinev 2002a). Some other species that are presumed to be members of the pulchella-group still await revision (Van Damme et al. 2010), and their affinities and differences with $A$. kaingang sp. nov. cannot be addressed yet.

Although there are several morphological differences between species in the pulchella-group and those related to species groups, Van Damme et al. (2013) indicated the possibility of identification mistakes. For example, some species of the pulchella-group has a postabdomen of a similar shape to the one observed in the Alona gutatta-group (e.g., A. archeri, A. glabra, and A. bromelicola). However, the Alona gutatta-group is a member of the Hexalona-branch, and the observation of the limbs is necessary (or at least the use of high magnification) for correct identification. Under low magnification, the postabdomen of $A$. kaingang sp. nov. resembles C. rectangula (= Alona rectangula), and many records of this species in Brazil (see Green 1972; Santos et al. 1994; Smirnov and Santos-Silva 1995; Eskinazi-Sant'Anna et al. 2005; Sterza and Fernandes 2006; Rocha et al. 2011; Viti et al. 2013) perhaps may be attributed to new species of the pulchella-group described here; this, however, needs to be checked.

From the evolutionary point of view, the pulchellagroup presents an interesting duality because its species do not have many specializations on the limbs (their morphology is almost constant) but differ in habitus and, mainly, in the morphology of the postabdomen. An extreme case was observed in A. capensis, which is similar in its limb morphology to other species of the group, but has an elongated body, a bulge on the rostrum, and 
a very peculiar postabdomen (Van Damme et al. 2013). Besides, the variability of shapes of the postabdomen in other species of pulchella-group (elongated, short and narrowing, short and massive, short and rounded; marginal denticles thick or thin; lateral fascicles short or long) suggests speciation mediated by evolutionary pressure on the movement, once postabdomen is the main morphological trait involved in such purpose, being also related to food collecting and shelter searching. The phylogenetic interpretation of the diversity of shapes of postabdomen in the pulchella-group still remains unclear, but elongated and short forms in different species may be arisen from adaptive convergence associated to similar environmental pressure.

As in other species group (e.g., Anthalona, Nicsmirnovius, Euryalona, Monospilus), the morphology of head pores may be important phylogenetically for the pulchella-group because of the absence of reductions or specializations in the limbs, that make difficult to do suggestions of affinities between species. However, in species with both morphologies of main head pores, a considerable level of affinities related to general shape of the postabdomen and fine structure on the limbs are observed: A. cambouei, a species with broken connection, has armatures of postabdomen and seta 5 of the limb III similar to species with complete connection, such as, $A$. pulchella and A. glabra (Sinev 2001b, c). When compared with the broken connection species $A$. nigra, $A$. aguascalientensis, and $A$. setulosa, $A$. cambouei presents differences in the armature of antenna, postabdomen, and proportions of setae on limbs I and III (Sinev 2001c, 2009; Sinev and Silva-Briano 2012). Therefore, morphology of main head pores could also be the result of convergence and to test relationship in pulchella-group may be useful to elucidate these issues.

The morphological boundaries of the pulchella-group indicate that it does not belong to the Alona sensu stricto (Van Damme and Dumont 2008a). It is probable that in the future, a new genus will be created and that will include A. kaingang sp. nov. (Van Damme et al. 2010). Moreover, the pulchella-group has many affinities with Ovalona Van Damme \& Dumont, 2008, a group recently removed from Alona. These two groups present affinities in habitus and limbs (mainly with Ovalona wei$n e c k i$ ), and the only feature that is truly different is the presence of the merged (pulchella-group) and not-merged (Ovalona) denticles on the postanal margin of the postabdomen (Van Damme and Dumont 2008b). The use of molecular tools can be valuable to define the relationship between the pulchella-group and Ovalona.

\section{Conclusions}

The pulchella-group is now composed of at least 15 valid species. The Neotropical fauna of the pulchella- group is extremely diverse and contains $50 \%$ of the known species. Alona kaingang sp. nov. has connection between main head pores complete; therefore, it is separated from A. setulosa, A. cambouei, A. aguascalientensis, A. nigra, A. setuloides, A. azorica, A. nuragica, A. capensis, and $A$. anastasia. Alona kaingang sp. nov. resembles A. altiplana but differs from it mainly in the morphology of the marginal denticles of the postabdomen and fine features on the limbs. The relationship between pulchella-group and Ovalana needs to be better studied.

\section{Abbreviations}

As: accessory seta; CBS: copulatory brush seta; EL: Elmoor-Loureiro collection, at Universidade Católica de Brasilia, Brazil; en: endite; ep: epipodite; ex: exopodite; fc: filtercomb; gfp: gnathobasic filter plate; gn: gnathobase; IDL: inner distal lobe; il: inner lobe; IP: interpore distance (distance between anterior and posterior major head pores); MNRJ: National Museum of Rio de Janeiro, Brazil; MZUSP: Museum of Zoology of the University of São Paulo, Brazil; ODL: outer distal lobe; pep: pre-epipodite; PP: postpore distance (distance between posterior major head pore and posterior border of head shield); s: sensillum; SEM: scanning electron microscopy.

\section{Competing interests}

The authors declare that they have no competing interests.

\section{Authors' contributions}

FDRS, LMAEL, and SS wrote the manuscript. FDRS and LMAEL produced the drawings, photographs on the SEM, and taxonomic discussion. SS discussed the taxonomic parts, made the intellectual contributions, and reviewed the manuscript. All authors read and approved the final manuscript.

\section{Acknowledgements}

We thank Prof. Dr. Maria José dos Santos Wisniewski and Dr. José Roberto Debastiani Júnior for providing the material from Furnas and São Simão reservoirs, respectively. Thanks to Prof. Dr. Ciro Joko for the suggestion about the digital scientific illustrations. We also thank Dr. Sônia N. Bao, Ingrid C. M. da Silva, and Márcia C. O. da Rocha (Electron Microscopy Laboratory of the University of Brasília), who made the SEM micrographs possible. We also thank MSc. Diego M. Magalhães and Ms. Susan Casement for revising the English version of this manuscript. We are grateful to Dr. Gilmar Perbiche Neves, Dr. Ricardo Lourenço Pinto, Carla Bender Kotizian, and Dr. Alexey Kotov for the suggestions on the initial draft of this manuscript. We are grateful to the anonymous reviewers for their valuable comments and suggestions on the manuscript. FDRS was awarded a grant from the Coordenação de Aperfeiçoamento de Pessoal de Nível Superior (CAPES). We are also grateful to the CNPq (Conselho Nacional de Desenvolvimento Científico e Tecnológico) for the productivity grant to SS (308598/2011-3).

Received: 27 January 2015 Accepted: 8 June 2015

Published online: 19 June 2015

\section{References}

Dumont JH, Silva-Briano M (2000) Karualona n. gen. (Anomopoda: Chydoridae), with a description of two new species, and a key to all known species. Hydrobiologia 435:61-78

Elmoor-Loureiro LMA (2004) Phylogenetic relationships among families of the order Anomopoda (Crustacea, Branchiopoda, Cladocera). Zootaxa 760:1-26

Eskinazi-Sant'Anna EM, Barbosa PMM, Rietzler AC (2005) Zooplankton biodiversity of Minas Gerais State: a preliminary synthesis of present knowledge. Acta Limnol Bras 17:199-218

Fonseca GAB (2010) Contribuição antrópica na poluição de reservatórios hidrelétricos: o caso da usina hidrelétrica de São Simão - GO/MG Universidade Federal do Rio de Janeiro, Dissertation

Fryer G (1968) Evolution and adaptive radiation in the Chydoridae (Crustacea: (ladocera): a study in comparative functional morphology and ecology. Philos Trans R Soc Lond B Biol Sci 254:221-384 
Green J (1972) Freshwater ecology in the Mato Grosso, Central Brazil. II. Associations of Cladocera in meander lakes of the Rio Suiá Missú. J Nat Hist 6:215-227

Kotov AA (2000a) Redescription and assignment of the chydorid Indialona ganapati Petkovski, 1966 (Branchiopoda: Anomopoda: Aloninae) to Indialonini, new tribus. Hydrobiologia 439:161-178

Kotov AA (2000b) Analysis of Kozhowia Vasiljeva \& Smirnov, 1969 (Chydoridae, Anomopoda, Branchiopoda), with a description of Parakozhowia n. gen. Hydrobiologia 437:17-56

Kotov AA (2003) Notes on Aloninae \& Grochowski, 1894 emend. Frey, 1967 (Cladocera: Anomopoda: Chydoridae): 1. Translocation of Alona incredibilis Smirnov 1984 to the genus Nicsmirnovius Chiambeng \& Dumont, 1999. Arthropoda Sel 12:167-170

Kotov AA (2006) Adaptations of Anomopoda crustaceans (Cladocera) to the benthic mode of life. Entomol Rev 8:210-225

Kotov AA, Elíaz-Gutiérrez M (2002) Analysis of the morphology of Spinalona anophtalma Ciros-Pérez \& Elíaz-Gutiérrez, 1997 (Aloninae, Anomopoda, Cladocera). Hydrobiologia 486:185-192

Kotov AA, Sanoamuang L (2004) Comments on the morphology of Nicsmirnovius eximius (Kiser, 1948) (Aloninae, Anomopoda, Cladocera) in Thailand, with description of its male. Hydrobiologia 519:117-125

Kotov AA, Sinev AY, Berrios VL (2010) The Cladocera (Crustacea: Branchiopoda) of six high altitude water bodies in the North Chilean Andes, with discussion of Andean endemism. Zootaxa 2430:1-66

Rocha O, Santos-Wisniewski MJ, Matsumura-Tundisi T (2011) Checklist de Cladocera de água doce do estado de São Paulo. Biota Neotrop 11:571-592

Sacherová V, Hebert PDN (2003) The evolutionary history of the Chydoridae (Crustacea: Cladocera). Biol J Linn Soc 79:629-643

Santos GB, Maia-Barbosa PM, Vieira F, López CM (1994) Fish and zooplankton community structure in reservoirs of southeastern Brazil: effects of the introduction of exotic predatory fish. In: Pinto-Coelho RM, Giani A, Sperling EV (eds) Ecology and human impact on lakes and reservoirs in Minas Geraia. SEGRAC Press, Belo Horizonte, pp 115-130

Santos RM, Negreiro NF, Silva LC, Rocha O, Santos-Wisniewski MJ (2010) Biomass and production of Cladocera in Furnas Reservoir, Minas Gerais, Brazil. Braz J Biol 70:879-887

Sinev AY (2001a) Redescription of Alona iheringi Sars, 1901 (Chydoridae, Anomopoda, Branchiopoda), a South American species related to A. rustica Scott, 1895. Hydrobiologia 464:113-119

Sinev AY (2001b) Redescription of Alona glabra Sars, 1901, a South American species of the pulchella-group (Chydoridae, Anomopoda, Branchiopoda). Arthropoda Sel 10:273-280

Sinev AY (2001c) Separation of Alona cambouei Guerne \& Richard, 1893 from Alona pulchella King, 1853 (Branchiopoda, Anomopoda, Chydoridae). Arthropoda Sel 10:5-18

Sinev AY (2002a) Place of a Central American bromeliad-inhabiting cladoceran Alona bromelicola Smirnov, 1988 within the genus (Branchiopoda: Anomopoda: Chydoridae). Arthropoda Sel 11:109-116

Sinev AY (2002b) Redescription of Australian cladocera Alona archeri Sars, 1888 (Branchiopoda: Anomopoda: Chydoridae). Arthropoda Sel 11:247-254

Sinev AY (2004a) Armatalona gen. n.-a new genus of subfamily Aloninae (Anomopoda, Chydoridae), separated from genus Alona Baird, 1840. Hydrobiologia 520:29-47

Sinev AY (2004b) Miralona gen. n.- - a new genus of the subfamily Aloninae (Anomopoda, Chydoridae) from Australia. Hydrobiologia 526:3-14

Sinev AY (2009) Notes on morphology and taxonomic status of some North American species of the genus Alona Baird, 1843 (Cladocera: Anomopoda: Chydoridae). Fundam Appl Limnol 175:59-77

Sinev AY, Atroschenko MM (2011) Revision of the genus Alonopsis Sars, 1862 and its position within Aloninae (Cladocera: Anomopoda: Chydoridae). Zootaxa 2800:1-17

Sinev AY, Elmoor-Loureiro LMA (2010) Three new species of chydorid cladocerans of subfamily Aloninae (Branchiopoda: Anomopoda: Chydoridae) from Brazil. Zootaxa 2390:1-25

Sinev AY, Hollwedel W (2005) Translocation of Alona muelleri Richard, 1897 into the genus Karualona Dumont \& Silva-Briano, 2000 (Branchiopoda: Anomopoda: Chydoridae). Arthropoda Sel 14:93-101

Sinev AY, Kobayashi T (2012) Redescription of the endemic Australian cladoceran Alona willisi (Smirnov, 1989) and its assignment to Acanthalona gen. nov. (Cladocera: Anomopoda: Chydoridae). Zootaxa 3390:43-45

Sinev AY, Kotov AA (2000) Redescription of Alona labrosa Vasiljeva\& Smirnov, 1969 (Chydoridae, Anomopoda, Branchiopoda). Hydrobiologia 439:125-139
Sinev AY, Kotov AA (2001) Redescription of Alona setosocaudata Vasiljeva \& Smirnov, 1969 (Anomopoda, Branchiopoda). Hydrobiologia 452:47-58

Sinev AY, Shiel RJ (2008) Redescription of Alona macracantha Smirnov and Timms, 1983 and its assignment to Maraura gen. nov. (Cladocera: Anomopoda: Chydoridae). J Nat Hist 42:2809-2824

Sinev AY, Silva-Briano M (2012) Cladocerans of genus Alona Baird, 1843 (Cladocera: Anomopoda: Chydoridae) and related genera from Aguascalientes State, Mexico. Zootaxa 3569:1-24

Sinev AY, Van Damme K, Kotov AA (2005) Redescription of tropical-temperate cladocerans Alona diaphana King, 1853 and Alona davidi Richard, 1895 and their translocation to Leberis Smirnov, 1989 (Branchiopoda: Anomopoda: Chydoridae). Arthropoda Sel 14:183-205

Sinev AY, Alonso M, Miracle MR, Sahuquillo M (2012) The West Mediterranean Alona azorica Frenzel \& Alonso, 1988 (Cladocera: Anomopoda: Chydoridae) is composed of two species. Zootaxa 3276:51-68

Smirnov NN (1971) Chydoridae fauny mira. Fauna USSR. Rakoobraznie, Leningrad. (English translation: Chydoridae of the world. Israel Program for Scientific Translations, Jerusalem, 1974

Smirnov NN, Santos-Silva EN (1995) Some littoral anomopods (Crustacea) from Central Amazonia. Hydrobiologia 315:227-230

Smirnov NN (1998) A revision of the genus Camptocercus (Anomopoda, Chydoridae, Aloninae). Hydrobiologia 386:63-83

Sousa FDR, Elmoor-Loureiro LMA, Santos S (2015) Redescription of the Coronatella poppei (Richard, 1897) (Crustacea, Branchiopoda, Chydoridae) and a revision of the genus in Brazil, with descriptions of new taxa. Zootaxa 3955:211-244

Sterza JM, Fernandes LL (2006) Distribution and abundance of Cladocera (Branchiopoda) in the Paraíba do Sul River estuary, Rio de Janeiro, Brazil. Braz J Oceanogr 54:193-204

Van Damme K, Dumont HJ (2007) Limb morphology of the carnivorous anomopods Anchistropus emarginatus Sars, 1862 and Pseudochydorus globosus (Baird, 1843) (Crustacea: Branchiopoda: Anomopoda). Ann Limnol - Int J Limnol 43:271-284

Van Damme K, Dumont JH (2008a) The True' genus Alona Baird, 1843 (Crustacea: Cladocera: Anomopoda): position of the A. qudrangularis-group and description of a new species from Democratic Republic of Congo. Zootaxa 1943:1-25

Van Damme K, Dumont JH (2008b) Further division of Alona Baird, 1843: separation and position of Coronatella Dybowski \& Grochowski and Ovalona gen.n. (Crustacea: Cladocera). Zootaxa 1960:1-44

Van Damme K, Dumont JH (2009) Notes on chydorid endemism in continental Africa: Matralona gen. n., a monotypic Alonine from the Fouta Djalon Plateau (Guinea, West Africa) (Crustacea: Cladocera: Anomopoda). Zootaxa 2051:26-40

Van Damme K, Sinev AY (2011) A new genus of cave-dwelling microcrustaceans from the Dinaric Region (south-east Europe): adaptations of true stygobitic Cladocera (Crustacea: Branchiopoda). Zool J Linn Soc 161:31-52

Van Damme K, Brancej A, Dumont HJ (2009) Adaptations to the hyporheic in Aloninae (Crustacea: Cladocera): allocation of Alona protzi Hartwig, 1900 and related species to Phreatalona gen. nov. Hydrobiologia 618:1-34

Van Damme K, Chiambeng G, Maiphe S, Dumont JH (2003) New species in the rheophilous genus Nicsmirnovius Chiambeng \& Dumont, 1999 (Branchiopoda: Anomopoda: Chydoridae) and reassignment of Alona eximia Kiser, 1948 and Alonella fitzpatricki Chien, 1970. Hydrobiologia 499:25-49

Van Damme K, Kotov AA, Dumont HJ (2005) Redescription of Leydigia parva Daday, 1905 and assignment to Parvalona gen. nov. (Cladocera: Anomopoda: Chydoridae). J Nat Hist 39:2125-2136

Van Damme K, Kotov AA, Dumont HJ (2010) A checklist of names in Alona Baird 1843 (Crustacea: Cladocera: Chydoridae) and their current status: an analysis of the taxonomy of a lump genus. Zootaxa 2330:1-63

Van Damme K, Sinev AY, Dumont HJ (2011) Separation of Anthalona gen.n. from Alona Baird, 1843 (Branchiopoda: Cladocera: Anomopoda): morphology and evolution of scraping stenothermic Alonine. Zootaxa 2875:1-64

Damme V, Bekker E, Kotov AA (2013) Endemism in the Cladocera (Crustacea: Branchiopoda) of Southern Africa. J Limnol 72:440-463

Viti T, Wisniewski C, Orlando TC, Santos-Wisniewski MJ (2013) Life history, biomass and production of Coronatella rectangula (Branchiopoda, Anomopoda, Chydoridae) from Minas Gerais. Iheringia, Sér Zool 103:110-117 